\title{
$「 \mathbf{A}\rfloor$ 砥粒中に存在する非晶質に就て (第 3 報)
}

\author{
非晶筫の螾出結果に就て
}

\author{
宮部 晋・監原穗並・西分谷嚴
}

\section{（1）緒 䨐}

前報に於てA 硅粒中に含末れる非晶質の熔出に適當な熔劑, 溫度 及び處理時間を知り得た。故に本報に於ては, 此のう法を用ひて試 驗的に製造された $2 ， 3$ の製品，並に市販品中代㳖的なる3種の製 品に就き愹出試驗を行ひ，熔出前後に於子る化學成分の變化，鑛物 學的變化を調べ，其の間の關係を檢討した。

\section{(2) 試蝌}

本試驗に使用した試粹の外觀及び性望は次の如くである.

Nö 1. ダイアスポアーを原料としたもので, 赤褐色, 玻璃光澤を 特ち、A 碰粒の基淮品々女云ふ可き外觀を呈す.

SK 12 に倒焰侙局垶 (燃料石炭) を以て燒成したりのは, 塊狀 をなするのに於ては黝青色に變色し，結晶間に無光澤，黃褐色の 确子物質の點々たる析出を見る. 又 46 に粉碎したりのは，黝 青色に變色無光澤黄褐色の硝子物質が析出散在して硅粒を僅に焙 結せしめてるる.

Nö 2. ボーキサイトを原料としたもので Nö 1 より僅に黑色癷つ た砥粒で, 强いて云へば黑裀色とも云ふ可きもの, 光澤は極めて 良好な玻璃狀である。

SK 12 に燒成したものは Nö1 より青䟞少なくネズミ色で,無 光澤, 黃褐色の确子物質の析出が非常に多く見られ，些 46 に粉 碎したものは, 非晶質の多いためか Nö 1 より燒結程度稍大きい。

Nö 3. 爐底の鐵合金が沈澱する上部に薄い嬮をなして出來るもの

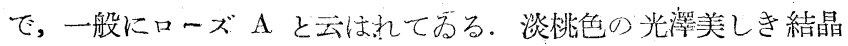
である．S远 12 に憢成したるのは溥ネズミ色を呈し, 前二者に比

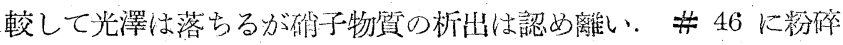
した粒も全々燒結の倾向がない。

Nö 4. 攀土頁岩を原料とし還元を充分行はなかつたもので, 塊に 氣泡多く, 光澤惡き黑色を旺してムライト狀の杜狀結晶が非常に 發達し長いるのは数粝に及んでるる。

SK 12 に塏成すれば属子化して光澤少なき黑色を呈するが，所 に依らムライト狀の結晶は其の供形を崩さず垡つてるる. \# 46 に 粉碎したものは, 固く焅結して光澤も良く, 燒成前の Nö $1, N o ̈$ 2 の如き色を呈し，表面が确子で蔽はれてるる粒がある.

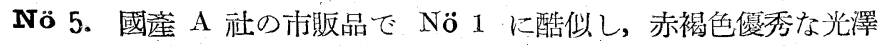

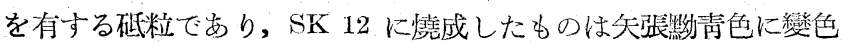
乙無光澤の硝子物質を析出するが，其の量は Nö 1, Nö 2 より少 く燒結も極めて僅である。

Nö 6. 國產 T 社製品で, 淡褐色にて透明感の弱い䂠粒で光澤も上 記の試料より劣つてるる．SK 12 に燒成した 46 の粒は䵢靑 色飞變じ，硝子物質の析出極めて多く，憢結も Nö 5 に次いで甚 しい.

Nö 7. 國産 TA 社製品で, Nö 2 を稍黑目にした黑褐色を呈し, 光澤も又惡い.SK 12 で燒成したものは䵢青色と淡褐色粒との混
合したものになり粒が幾分膨脹崩壤の傾向を示めし，燒結は極め て少ない。

\section{(3) 試 驗 方 法}

各試驗を道じて試料は此等 7 種共に \#46 を用ひて行つた。

i. 熔出 試科 $2 \mathrm{~g}$ を精科し, 前號既報の广法に依り, アルカリ

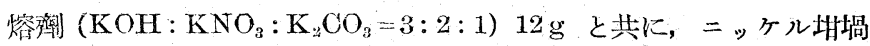
に入れ，電篓爐中で徐々に溫度を上最せしめ $800^{\circ} \mathrm{C}$ に至り, 之の溫 菖を保つ事 5 時間, 其の間 5 分乃至 10 分每に內容物を攪拌しつ つ溶出を助ける。後; 此れを爐より取出して水で浸解, 東洋爐紙 Nö

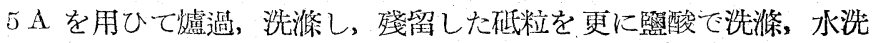
後乾燥, 科量する. 之の減量を以て榕出量とし, 濾液は之を濃縮, 熔 出アルミナを定量する，粒は其の一部を採り分析試料とし，他を以

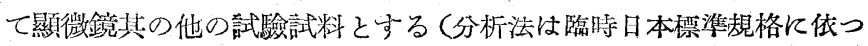
(行つた).

ii. 顯微鏡寫檤 非晶質友びュランダム以外の不純物を明嘹に觀 察するために屈折率のコランダムに近似してるる沃化メチレンを漫 液とし，熔出前後のものを本行ニュル下 30 倍に撮影した.

iii. 屈斩高 A 䃌粒の屈折率は結晶內に含まれる不純物の量に 影響する事が谜しいと云はれてるる。故に、熔出噪作に低つて固熔體 として疮在する物翼の熔出が行はれるとすれば, 屈折率子熔出前後 飞於て變化する譯である。此の點を確める篇に熔出操作前後に於い ての䂠粒の屈折譬を測定して見た.

iv. 比管 ピクノメーターに位らず, 試料を直徑約 $20 \mathrm{~mm}$, 長さ 約 $50 \mathrm{~mm}$ のガラス製圓鑄》に大れ，毛髮を以て比重既知の石油中 に奬吊して科量する方法を用ひた。

v. 燒絬度試驗 愹出前の試料に就いてセメント試驗規格の抗張 力試驗を應用した。郎ち試驗を粉倅する事なしに $2 \%$ の蛙目粘土々 少量のデキストリンを加へて氷で混練したものを，秥打機で製形し SK 16 に燒成後, ヘアバンク抗張力試驗機にかけ, $\mathrm{cm}^{2}$ 當りの抗張 力を以て槷結度を表してみた。

\section{(4) 試 驗 結 果}

以上の方法に依り 7 種の A 䃌粒に就て行つた試驗結果は次表に 示す如くで交つた.

\section{（5）總括}

上記㬎微鏡寫貪及び結果を比較檢討して吾々の知り得た所を總括 すれば次の如し.

1. 前報に於けると同じく, 本試驗に於ても\#46 を熔出した結 果は粒表面の非晶質の大部分を熔出せしめて, 熔出後の硑粒は僅な 粒の氣孔中に存在する非晶質を殘すに過ざない。

2. 熔出の不滿足であつた No. 7 は電氣爐熔融時に充分溫度が上 年せず，若干熔融不足で粘稠度の高い熔融物を急冷したものと思は れる砥粒であり，直交ニコル下に檢鏡すれば明に集晶である事が認 


\begin{tabular}{|c|c|c|c|c|c|c|c|c|c|c|c|c|c|c|}
\hline \multirow{2}{*}{\multicolumn{2}{|c|}{ 試料播號 }} & \multirow{2}{*}{\multicolumn{3}{|c|}{ 試料狀態 }} & \multicolumn{3}{|c|}{ 化 } & 學 & \multicolumn{3}{|l|}{ 組 } & \multirow{2}{*}{$\begin{array}{l}\text { 属折率 } \\
\text { No. } \omega\end{array}$} & \multirow{2}{*}{ 比重 } & \multirow{2}{*}{$\begin{array}{c}\text { 燒 結 度 } \\
\text { (5 回の本均) }\end{array}$} \\
\hline & & & & & $\mathrm{SiO}_{2}$ & $\mathrm{Fe}_{2} \mathrm{O}_{3}$ & $\mathrm{TiO}_{2}$ & $\mathrm{CaO}$ & $\mathrm{MgO}$ & $\mathrm{MnO}$ & $\mathrm{Al}_{2} \mathrm{O}_{3}$ & & & \\
\hline \multirow[t]{3}{*}{ Nö } & 1. & 原 & 試 & 料 & 1.95 & 0.07 & 3.26 & 0.38 & 0.21 & 0.02 & +94.12 & 1.7695 & 3.962 & $124 \mathrm{gr} / \mathrm{cm}^{2}$ \\
\hline & & 签 & 出 & 粒 & 0.08 & 0.01 & 1.28 & 痕跡 & 狼跡 & 0.01 & +94.02 & 1.7695 & 3.976 & + \\
\hline & & 铝 & 出 & 液 & $\dagger 1.87$ & +0.06 & +1.98 & † 0.38 & $\dagger 0.21$ & $\dagger 0.01$ & 0.10 & $-\cdots$ & - & - \\
\hline \multirow[t]{3}{*}{ Nö } & 2 & 原 & 試 & 料 & 2.16 & 0.15 & 2.82 & 0.34 & 0.21 & 0.03. & $\dagger 94.29$ & 1.7697 & 3.952 & 137 \\
\hline & & 镉- & 出 & 粒 & 0.08 & 0.05 & 1.03 & 痕跡 & 同左 & 同左 & +93.48 & 1.7697 & 3.971 & $\cdots$ \\
\hline & & 熔 & 出 & 湤 & +2.08 & +010 & +1.79 & †. 3.34 & +0.21 & 0.03 & 0.81 & - & $\therefore$ & $\because$ \\
\hline \multirow{3}{*}{ Nö } & 3 & 原 & 試 & 料 & 0.17 & 0.21 & 0.58 & 0.12 & 0.12 & 痕跡 & $\dagger 68 ; 97$ & 1,7695 & 3.968 & 360 \\
\hline & & 熔 & 出 & 粒 & 0.01 & -0.20 & 0.50 & 痕跡 & 同左 & 同左 & +98.59 & 1.7695 & 3.573 & $\div$ \\
\hline & & 簽 & 出 & 液 & +0.16 & +0.01 & +0.08 & $\dagger 0.12$ & $\dagger 0.12$ & 痕跡 & 0.20 & - & $\therefore \quad \therefore$ & - \\
\hline \multirow[t]{3}{*}{$\mathrm{Nö}$} & 4 & 原 & 試 & 料 & 19.23 & 2.60 & 3.25 & 0.47 & 0.55 & 0.07 & † 73.83 & 不 测 & 不測 & 630 \\
\hline & & 熔 & 出 & 粒 & 8.05 & 1.12 & 0.50 & 0.25 & 党跡 & 0.02 & +68.15 & 同上 & 同上 & - \\
\hline & & 熔 & 出 & 液 & $\dagger 11.18$ & $\dagger 1.48$ & $\dagger 2.75$ & $\dagger 0.22$ & $\dagger 0.55$ & $\dagger 0.05$ & 5.68 & - & - & - \\
\hline \multirow[t]{3}{*}{ Nö } & 5 & 原 & 試 & 料 & $=1.44$ & 0.17 & 2.20 & 0.38 & 0.32 & 0.04 & +95.45 & 1.771 & 3.953 & - \\
\hline & & 熔 & 出 & 粒说 & 0.06 & 0.06 & 0.94 & 0,03 & 0.03 & 将跡 & +91.26 & 1.771 & 3.975 & -- \\
\hline & & 熔、 & 出 & 液 & +1.38 & $\dagger 0.11$ & +1.26 & +0.35 & +0.29 & 0.04 & 4.19 & -- & - & - \\
\hline \multirow[t]{3}{*}{ Nö } & 6 & 原 & 誡 & 料 & 4.56 & 0.16 & 3.15 & 0.40 & 0.39 & 0.07 & $\dagger 91.30$ & 1.7715 & 3.925 & - \\
\hline & & 熔 & 出 & 粒 & 痕䟽 & 0.05 & 0.98 & 0.07 & 痕䟽 & 泿跡 & $\dagger 91.08$ & 1.7715 & 3.970 & -- \\
\hline & & 噡 & 出 & 液 & $\dagger 4.56$ & +0.11 & $\dagger 2.17$ & $\dagger 0.39$ & $\dagger 0.36$ & $\dagger 0.07$ & 0.22 & $\ldots$ & - & - \\
\hline \multirow[t]{3}{*}{$\mathrm{Nö}$} & 7 & 原 & 践 & 料 & 0.39 & 0.18 & 1.72 & 0.18 & 0.10 & 0.03 & $\dagger 97.40$ & 1.771 & 3.975 & $\cdots$ \\
\hline & & 焀 & 出 & 粒 & 0.12 & 0.09 & 1.19 & 0.10 & 0.03 & 痕跡 & +96.68 & 1.771 & $3.970^{\circ}$ & $\ldots$ \\
\hline & & 熔 & 出 & 液 & $\dagger 0.27$ & $\dagger 0.09$ & $\dagger 0.53$ & +0.08 & +0.07 & 0.03 & $\quad 0.72$ & - & - & - \\
\hline
\end{tabular}

N̦o. 1.

沃化メチレン浸液メ30

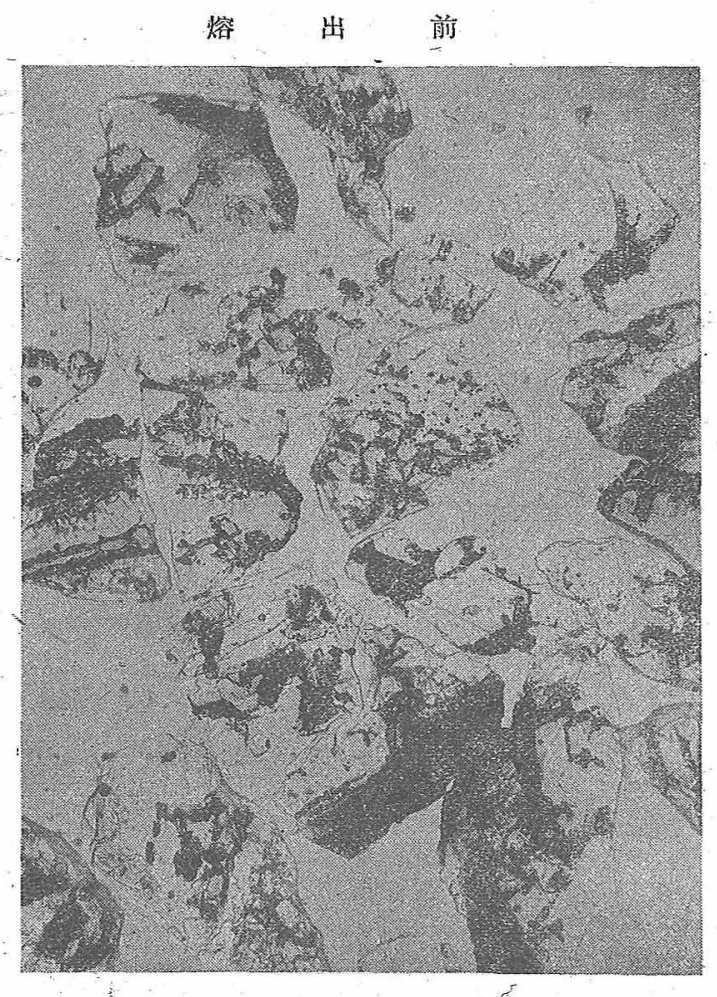

められる，郎ち非晶質が多量に表面に附着してるる小結晶粒が數個 密着して一個の秪粒を形造つてるる．故に熔缡がこの低粒內部の小， 結晶面上の非晶質迄も熔出せしめる事が出來ない，

3. Nö 4 は球酸が充分分離されてるない粒で, 粒中に多量のん

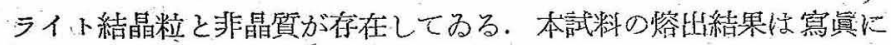
明な如?，ムライト粒はコランダム粒に比して著しく侵蝕され總て 角を失ひ丸味を帶び，小さくなつてるる。郎ち本熔劑はコランダム

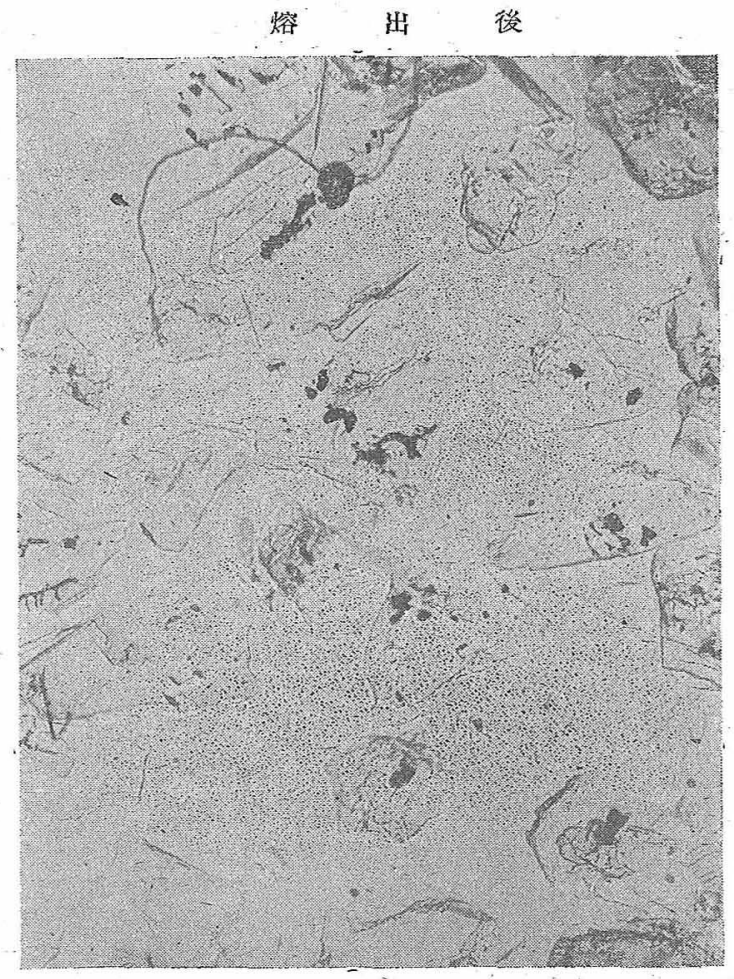

よりるムライトを侵㖉する作用が甚しく顯著である.

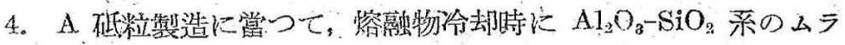
イト包晶反鷹があるとすれね゙，此の方法で熔出を行つた時前項の事 一實方ら粒表面のムライトは愹出される譯で多る。但本試驗の結果に よれば愹液畃のアルミナ量は墔酸に比しムライトに相當するよりは

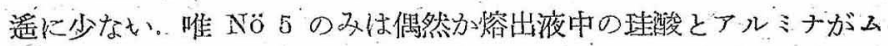
ライトを想像せしめ得る如き制合に存在してるる，包晶反臀が起る 
No. 2.

沃化 メチレン浸液 $\times 30$.
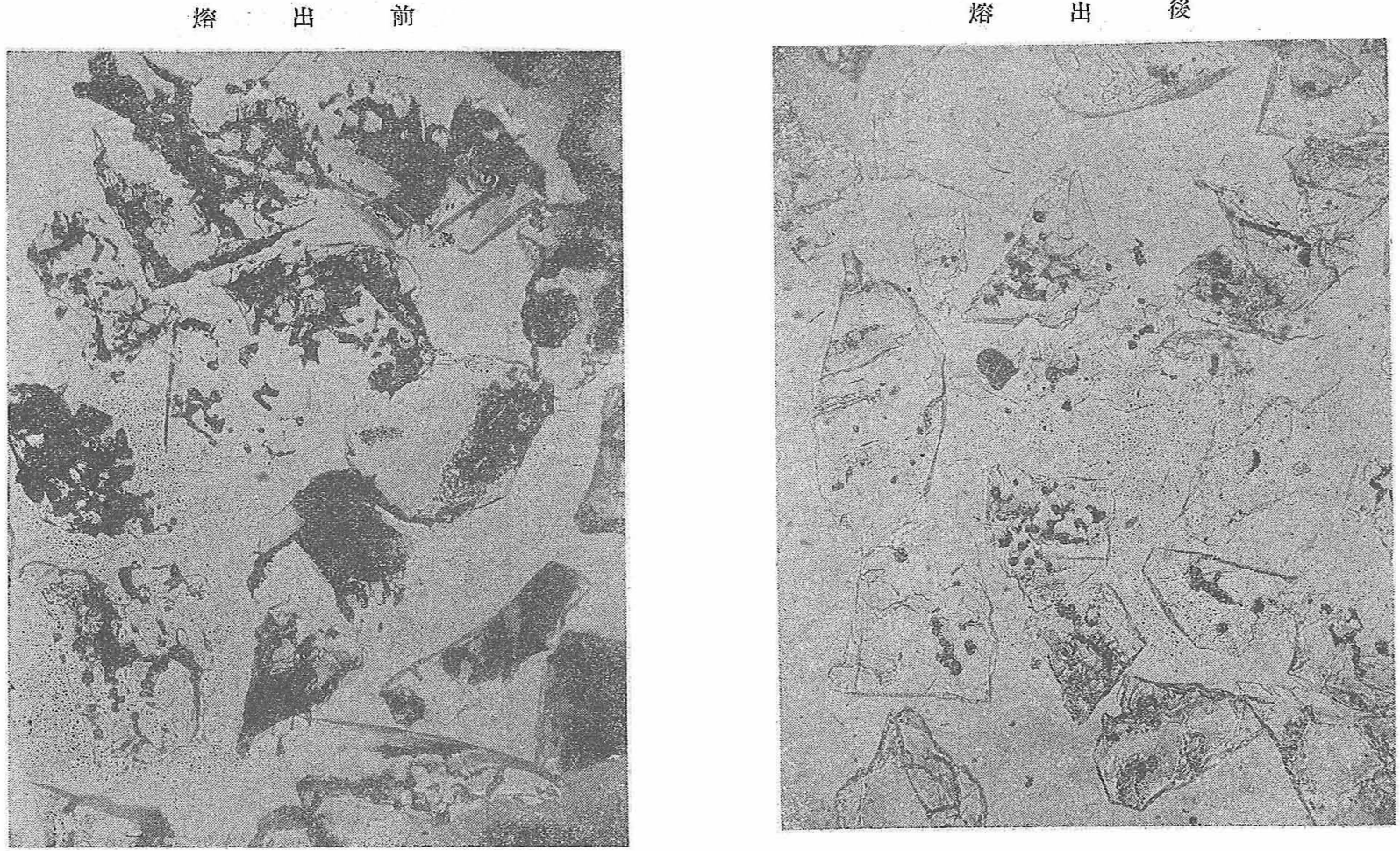

No. 3.

沃霜化メチレン浸液 $\times 30$

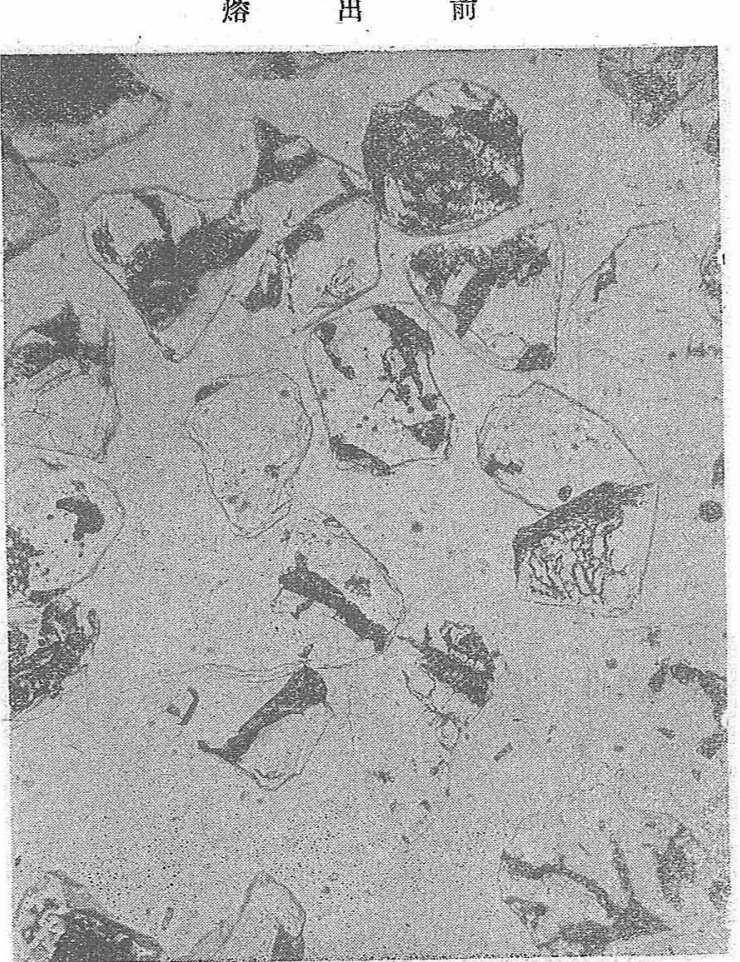

や否やの決定は後の試驗に持たなければならぬ

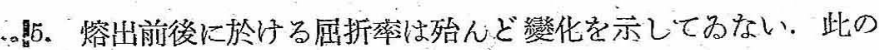
事實は熔出に依つて結晶中に固溶體として大つて居る不純物は變化 を受け好事を示してるる。命炎熔出處理に倅つて完全に非晶質を取 除く事は出來なかつた故，屈新率と固溶體として大る不純物の量と の關係ほ見出し得なかつた。

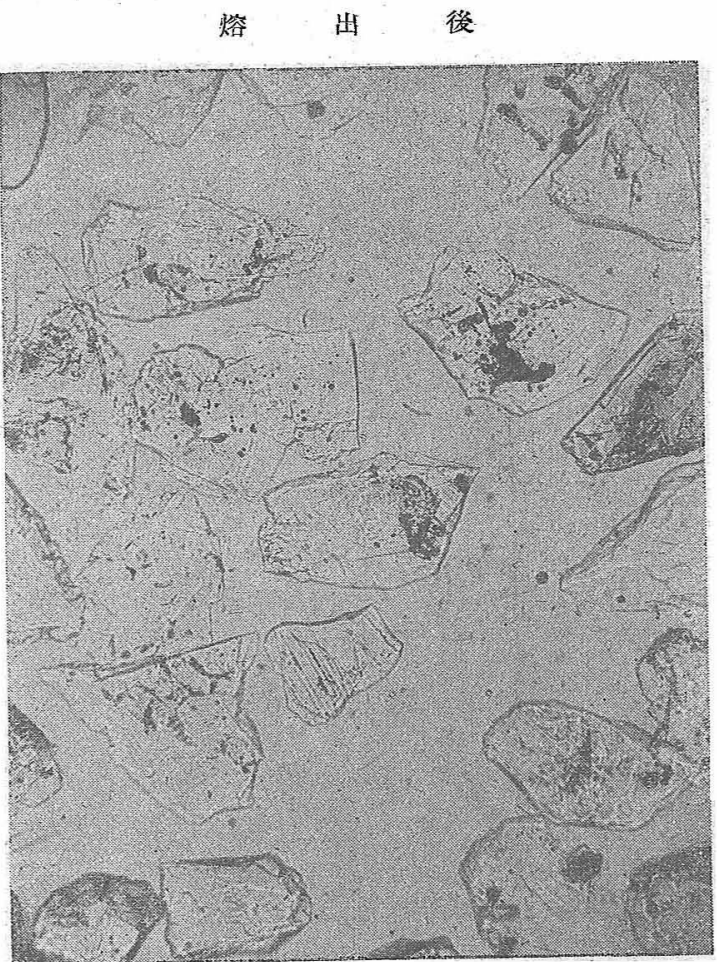

6、熔出處理をした粒は熔出前の竝よりも比重が大きくなり，こ の傾百は塔出前の砥粒に理酸含量の多いるの程甚しい樣である. 即 ち珪酸含量の $0.17 \%$ でるる Nö 3 は比重 0.005 增加に過ざないが， 珪酸合量 $2 \%$ 內外の Nö 1 , Nö 2, Nö 5 等になる と約 0.02 を增加 し，4.56\% 学含む Nö 6 に於ては比重む文 0.05 を壻加してるる. いづれにしても熔出後の粒の比重は $3.970 〜 3.975$ の範圍にある故 
No. 4.

沃化 メ $テ$ ン浸波 $\times 30$
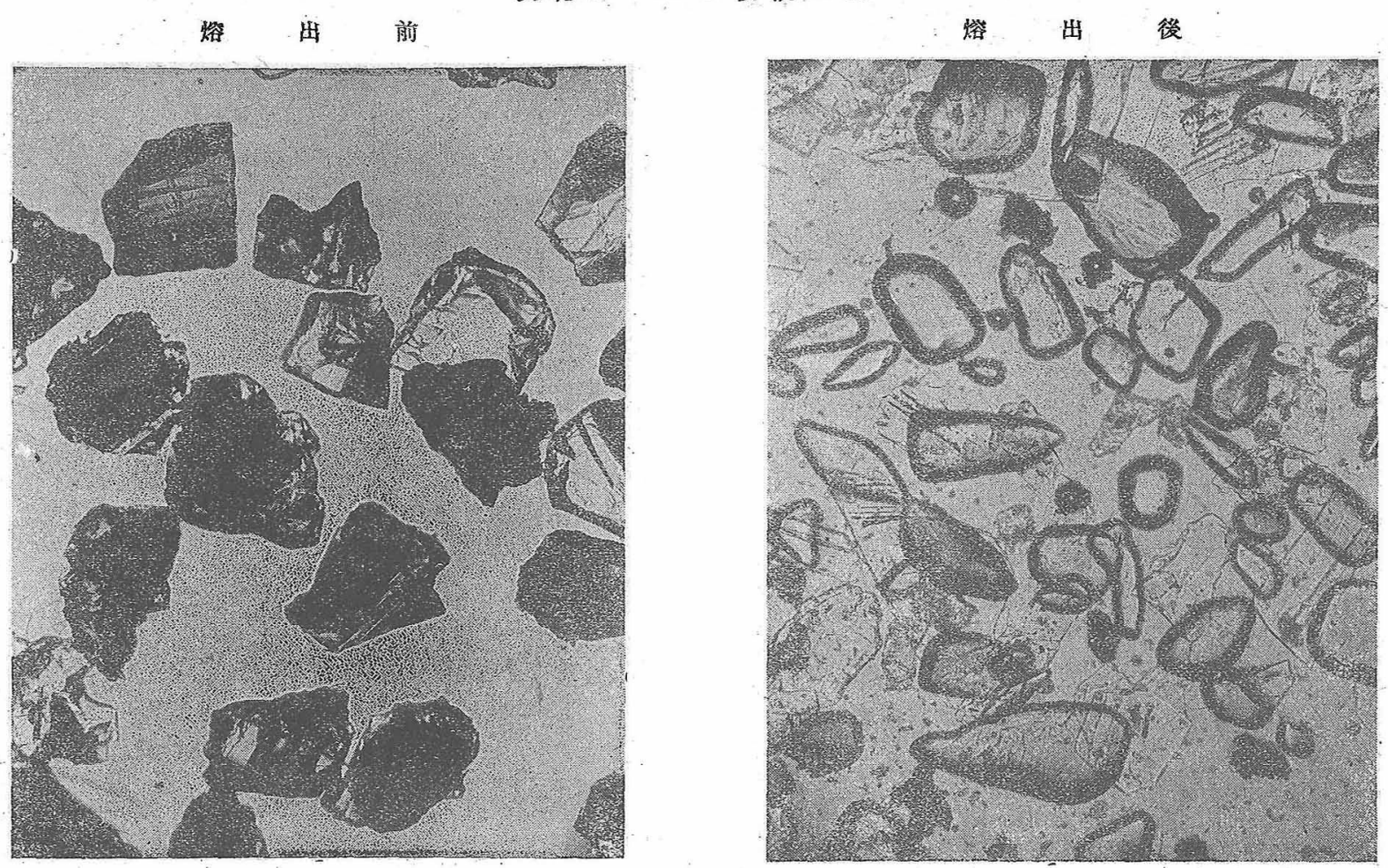

No. 5.

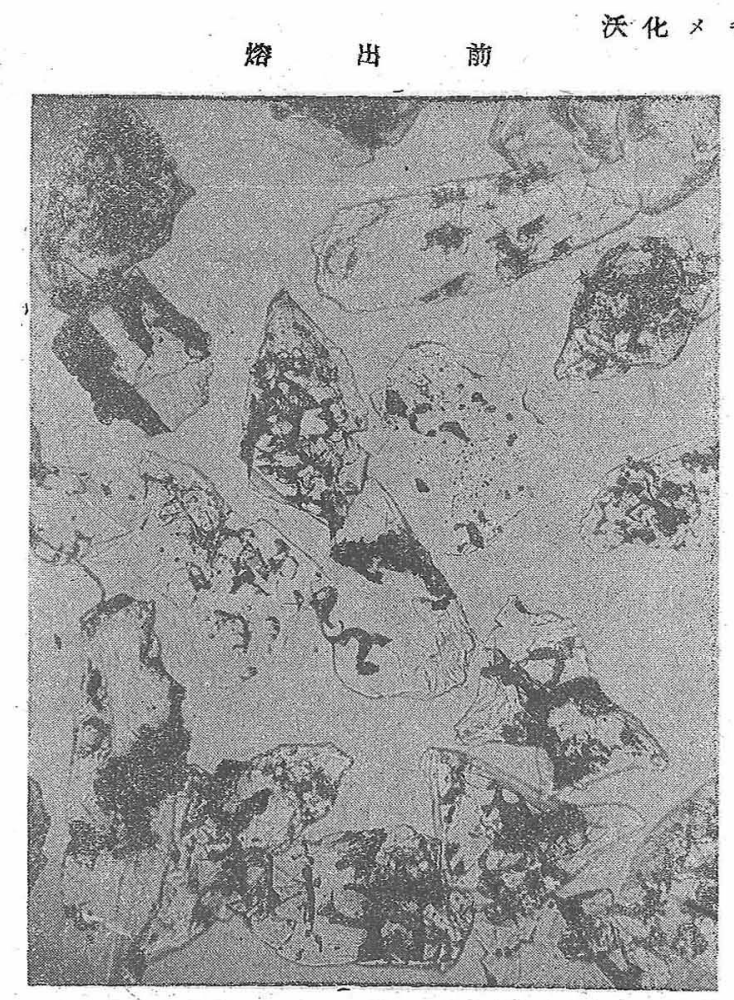

純粹な結晶部分の比重は此の近くの值を持つ事は磪であり，所謂非 晶質の比重は此れに比し遥に低いるのである.

7. 愹出後の糧の分析結果を見れぱ明なる如く，處理啳の粒は殆 んど大部分がナルミナで， $1 \%$ 円外の酸化チタン+酸化デルコンと

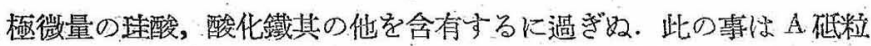
の本質を左右せしめるものは酸化チタン（及び酸化デれゴン）のみ で，他は大部分結晶外に析出してコランダム以外の結晶文は非晶質

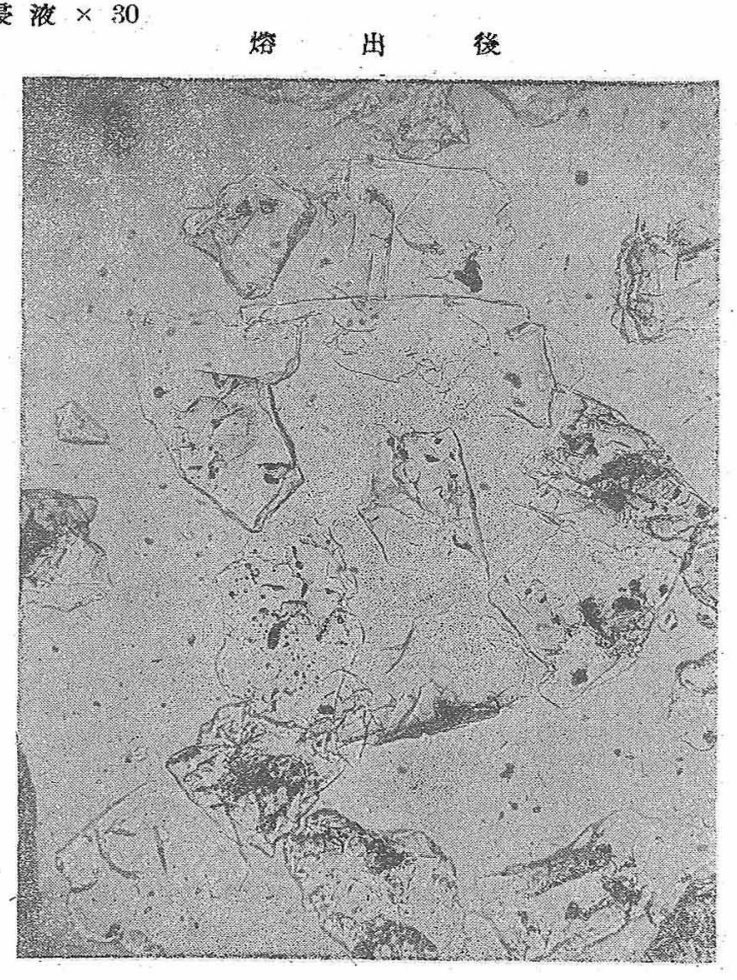

を形造るるのと思はれる. コランダム結晶內に固溶體として入り得

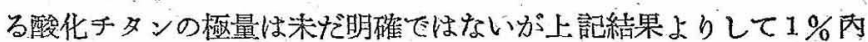
外である高は欮言し得る。

8。嶢結の原因をなす物質は，䞍酸を主體として酸化鐵，酸化千 タン, 酸化デルさン, 不疢, 苦土等を含んぞ低悢酸化物よりなる非 晶筫で岕る(第 1 嘏參照)。

9. 蛙目の少量を賦形劑として與へた燒結試驗が上記 (8) の結果 
No. 6.

沃化メチレン浸液 $\times 30$
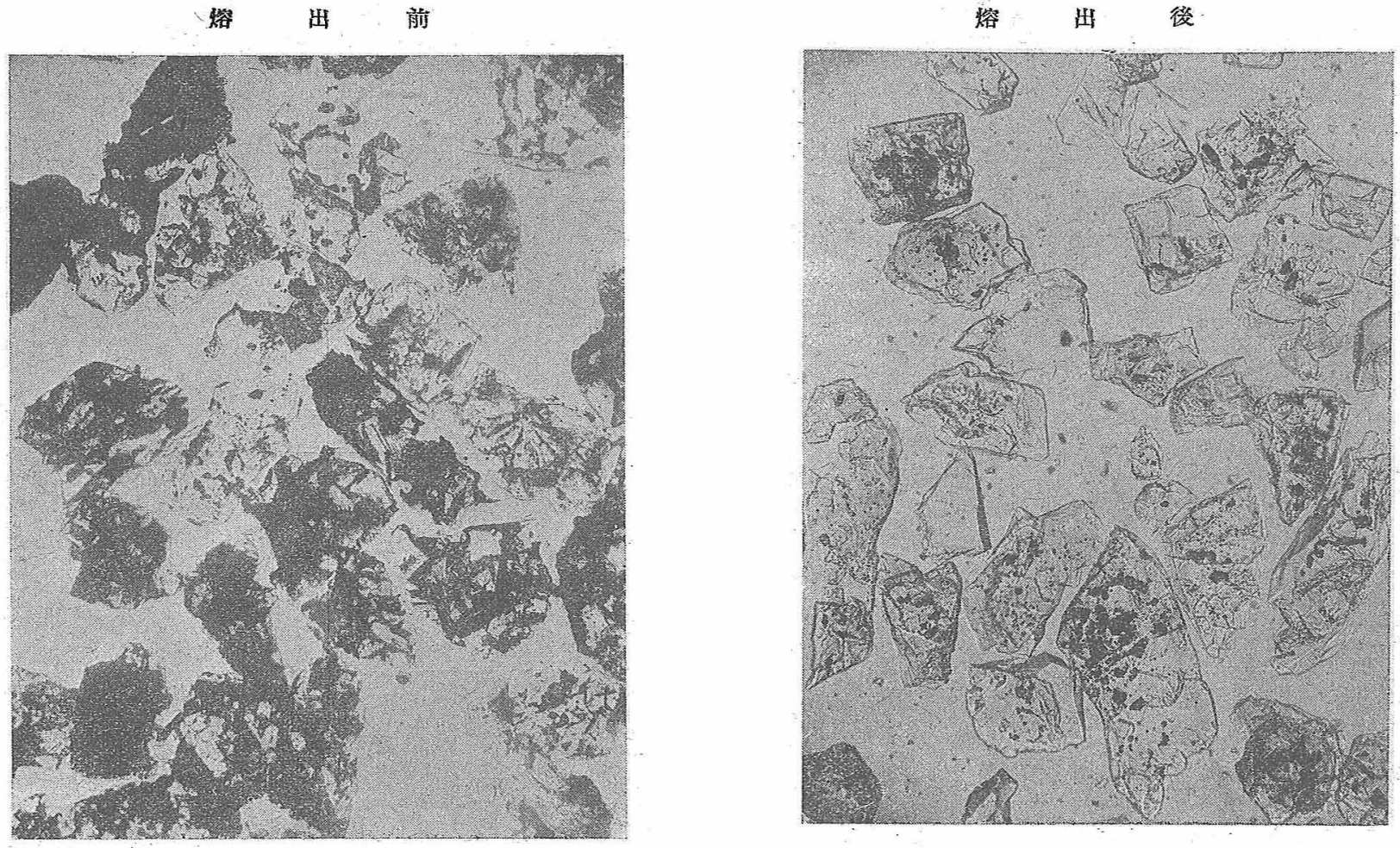

No. 7.

熔出前

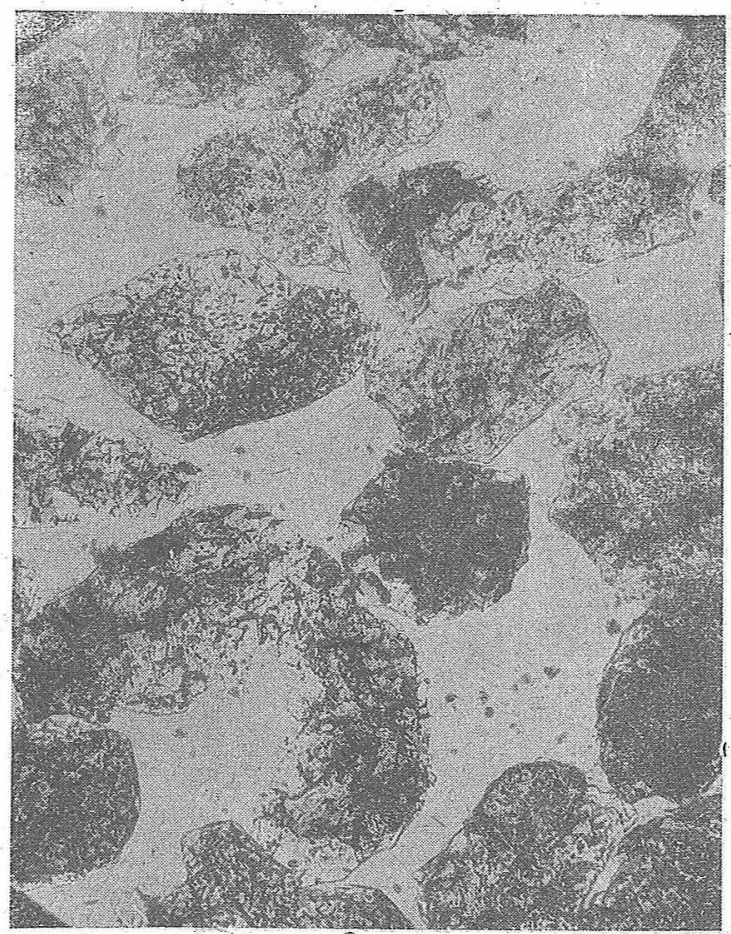

そ全く相反する結果を示めしてるる。此の事は磁化法 (vitrifiedme

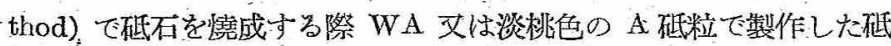
石のオが普通のA 砥粒で製作した砥石より，同一條件に於て硬く 出來上る事實と相通ずるものと考へられる。原因は未失明ではない が，橈成時に，粒の表面に附着してるる确子質が酸化炤中で安定な 形に轉化する際發泡しボンドとの中間に脆い、層を作る冎ですると考
レン浸液 $\times 30$

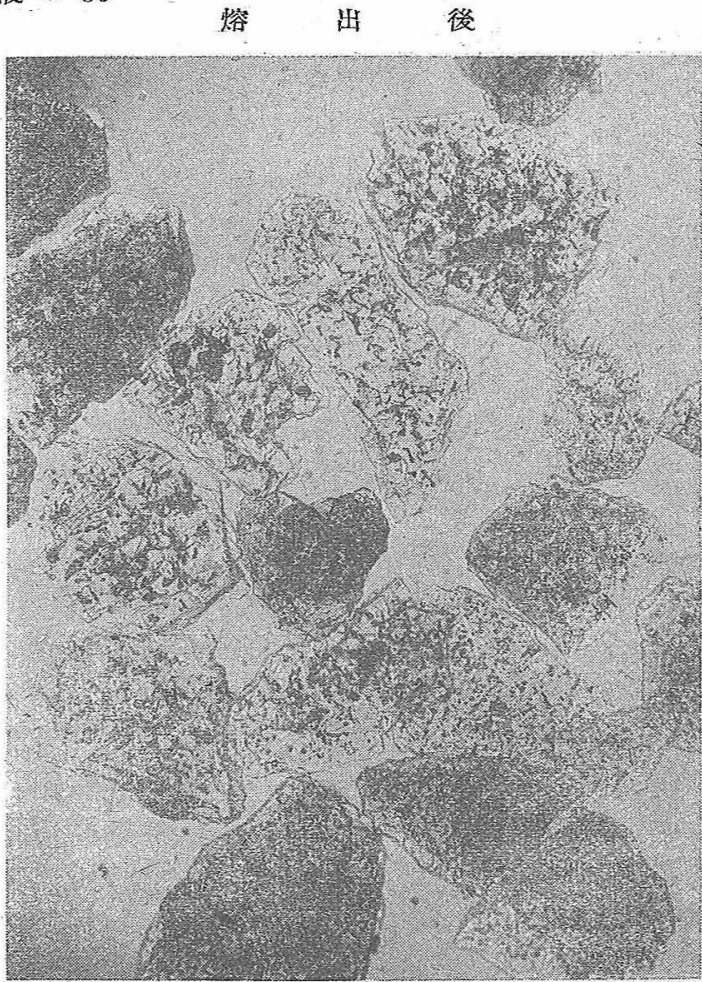

へられる.此の曆は更に長特間䯩溫に會へば, ボンドと融け合ひ A 研粒に密着して硬い砥石を作るのではなかららか。

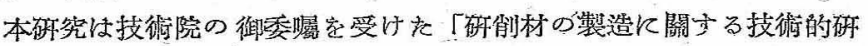

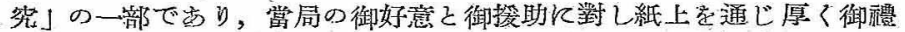
申上げる次第である。文, 本研究に就て終始御指導, 衔援助を賜つた

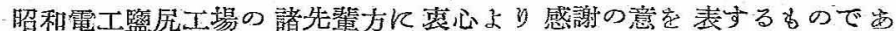
る。(昭和 18 年 6 月 25 日 昭和電工株式會社 籃尻工場研究課) 